\title{
The Growing Role of Photovoltaic Solar, Wind and Geothermal Energy as Renewables for Electricity Generation
}

\author{
Wilfried G.J.H.M. van Sark ${ }^{1}$, J. Gerard Schepers ${ }^{2,3}$, \\ and Jan Diederik A.M. van Wees ${ }^{4,5}$ \\ ${ }^{1}$ Copernicus Institute of Sustainable Development, Utrecht University, The Netherlands \\ ${ }^{2}$ ECN Wind Energy Technology, The Netherlands \\ ${ }^{3}$ University of Applied Sciences NHL, The Netherlands \\ ${ }^{4}$ TNO Sustainable Geo-Energy TNO, The Netherlands \\ ${ }^{5}$ Department of Earth Science, Utrecht University, The Netherlands
}

\subsection{General Introduction}

Since the start of the new millennium the installed amount of renewables-based energy technologies has increased at steady annual growth rates of 2-30\%, depending on the specific technology. At the end of 2013, the share of renewables in fulfilling the primary energy demand is about $19 \%$, of which traditional biomass takes up about $50 \%$ [1], while their share in electricity is $22 \%$. Figure 2.1 illustrates the dominance of fossil fuels in global electricity production, which will be challenged in the decades to come by a combination of renewables. Total electricity generated is $22668 \mathrm{TWh}$ (end 2012) at a total installed power capacity of $5800 \mathrm{GW}$ [2], which corresponds to an average global capacity factor of $45 \%$. Presently, about three-quarters of renewable power is generated by hydropower $(1000 \mathrm{GW})$, followed by wind $(318 \mathrm{GW})$, solar-PV (photovoltaic solar energy) $(139 \mathrm{GW})$, bio-power $(88 \mathrm{GW})$, geothermal $(12 \mathrm{GW})$, concentrated solar power $(3.4 \mathrm{GW})$,

Sustainability Assessment of Renewables-Based Products: Methods and Case Studies, First Edition. 


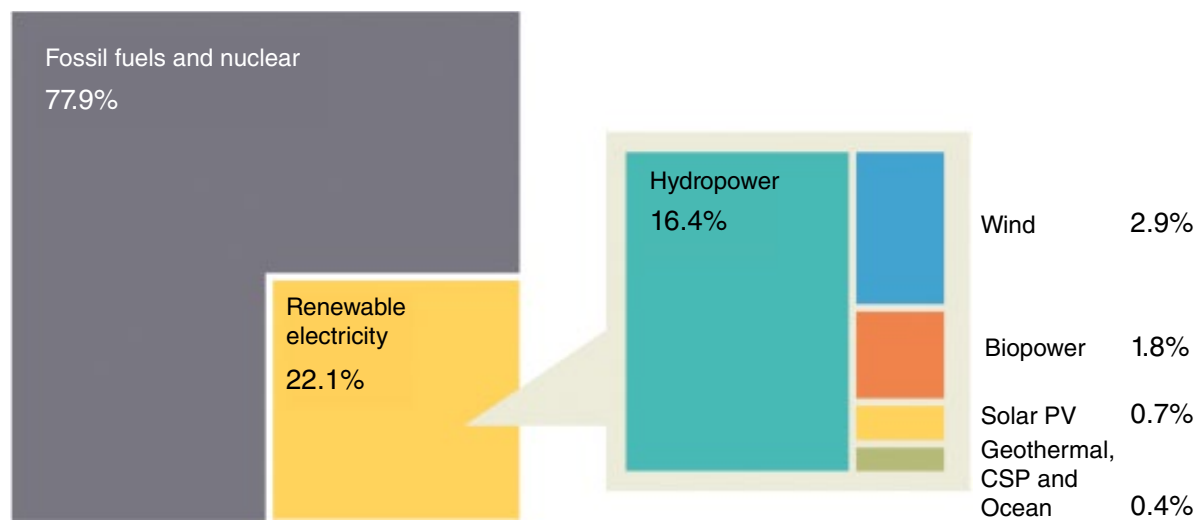

Figure 2.1 Share of renewables in global electricity production (end 2013) [1]. Source: Reproduced with permission from REN21 [1]. (C) REN21.

and ocean energy $(0.5 \mathrm{GW}$, mainly tidal) [1]. Note that capacity factors of renewable technologies are usually lower than typical capacity factors of $80 \%$ for coal-fired power plants. The growth in renewable power capacity is shown in Figure 2.2.

Global investments in renewable power have increased from $\$ 40$ billion in 2004 to $\$ 214$ billion, where it is interesting to observe that in the past 2-3 years, investment in the United States and Europe has declined, and that investment in China now is the largest (at $\$ 56$ billion) [2]. Likewise, the amount of jobs in renewable energy has more than doubled from 3 million in 2004 to 6.5 million at the start of 2014, where it should be noted that about $25 \%$ of these are related to solar-PV in China. Most renewable technologies have seen a mild to steep decrease in cost, for example, the cost of solar-PV decreased by $50 \%$ between 2010 and 2014. This has led, for all technologies, to levelized cost of energy (LCOE), which is competitive with non-renewable electricity cost (of between 5 and $10 \phi /$ $\mathrm{kWh}$ ). For residential solar-PV, in many countries so-called retail-grid parity has been reached, that is, LCOE is lower than the retail electricity price.

In several countries, high levels of penetration of renewables are found [1]: Denmark generates 33\% of its 2013 annual electricity demand by wind power and in Spain wind amounts to $20.9 \%$. Solar-PV generates $7.8 \%$ of the annual electricity demand of Italy. These variable renewable technologies are integrated in networks, while flexible (or controllable) renewables such as hydropower are increasingly being used for balancing. Also, geothermal and bio-power can provide balance power. Penetration of geothermal energy is already high in Iceland, at 29\% [1].

Increased amounts of renewable energy generation contribute to decrease in greenhouse gas (GHG) emissions. As an example, Germany had $77 \mathrm{GW}$ renewable capacity installed in 2012 (5.6 GW hydro, 31.3 GW wind, 7.5 GW bio, 32.6PV), which generated $143463 \mathrm{GWh}$ (with average capacity factor of 21\%) [3]. This led to avoided GHG emissions of $101.8 \mathrm{Mt}$, or $710 \mathrm{gCO}_{2}$-eq/kWh. Now, assuming that $1560 \mathrm{GW}$ renewable capacity runs at similar capacity factor, which may be questionable, global avoided GHG emissions would amount to $2 \mathrm{Gt}$, which is already quite considerable compared with 2013 global emissions of 36.1 Gt [4].

In this chapter, the focus is on developments in photovoltaic solar energy, wind energy, and geothermal energy. 
(a)

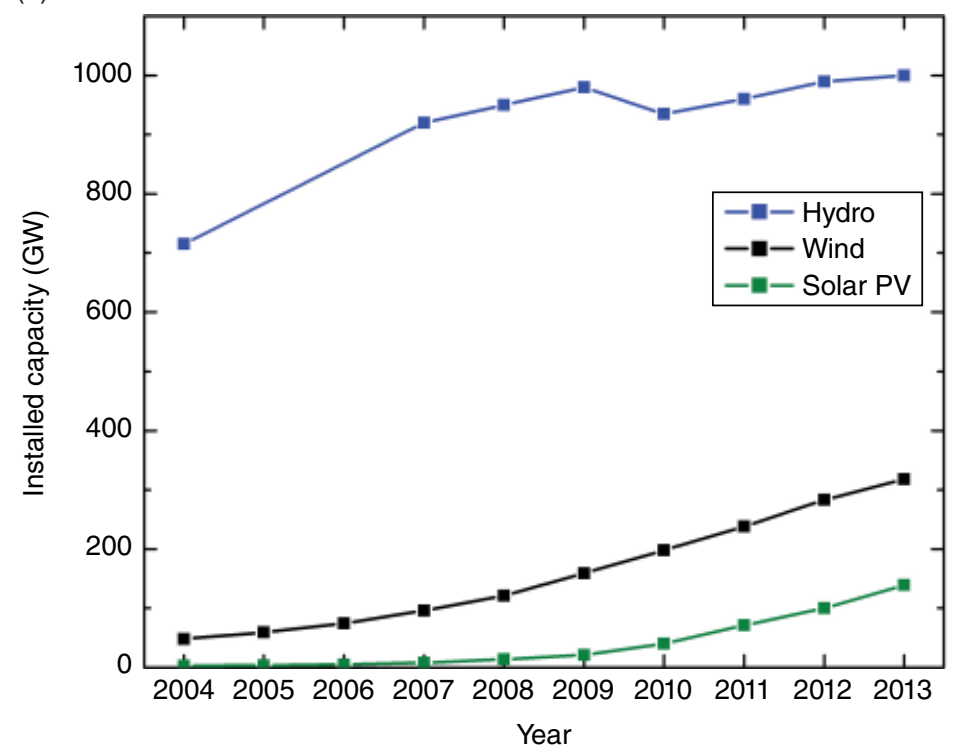

(b)

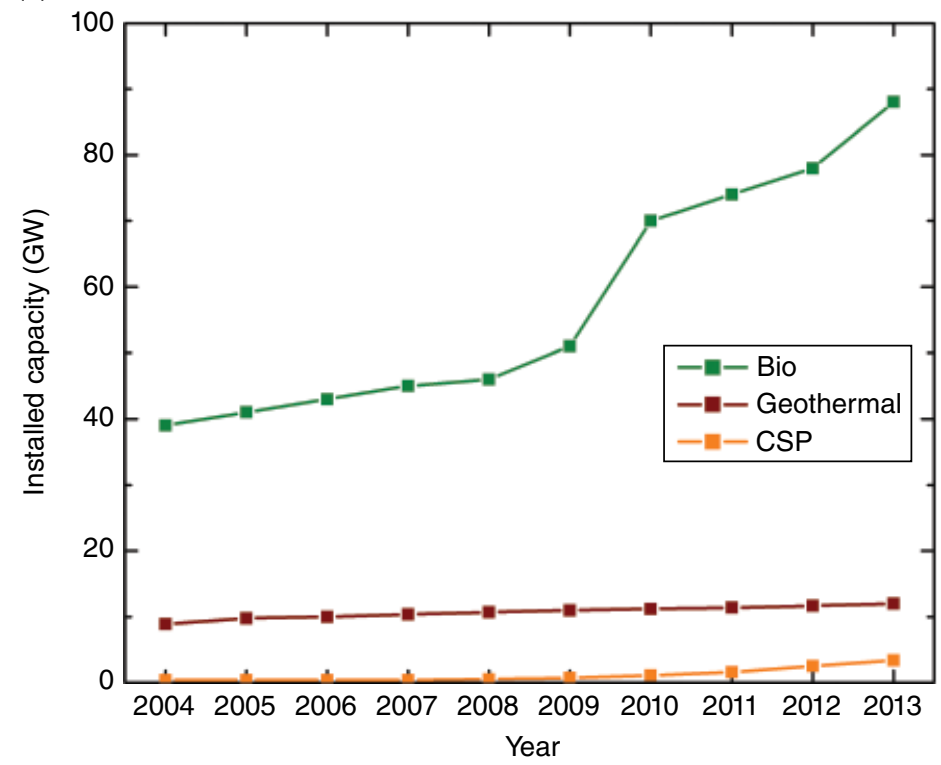

Figure 2.2 Total installed capacity of renewable power between 2004 and 2013. (a) Hydro, wind, solar PV; (b) Bio, geothermal, CSP. Source: Data from REN21 [2].

\subsection{Photovoltaic Solar Energy}

Although Becquerel discovered the photovoltaic effect, that is, the conversion of photons to electricity in 1839 [5], it took over a century before solar cells were developed at Bell Telephone Laboratories in the United States [6]. The solar cells were called silicon solar energy converters commonly known as the Bell Solar Battery [7]. At present, various applications of photovoltaic 


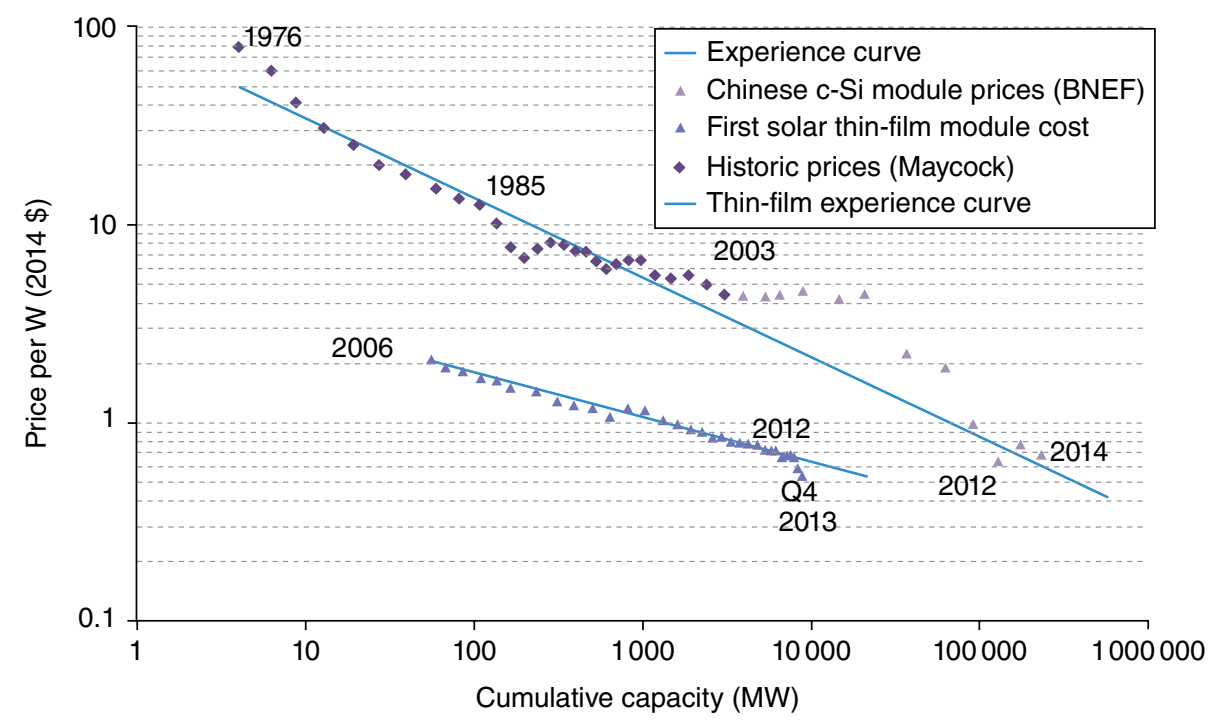

Figure 2.3 PV experience curve [11]. Source: Reproduced from Chase [11], with permission from Bloomberg New Energy.

solar cells exist ranging from stand-alone PV systems, satellites, grid-connected PV, building integrated PV systems, and very large systems with a power of tens of megawatts [8].

Photovoltaic solar energy has evolved in the past decade into a major renewable electricity supplier with a total installed capacity of $135 \mathrm{GW}$ [9], albeit contributing just about $1 \%$ of the world's electricity demand. Investment incentives as well as support mechanisms such as the feed-in tariff pioneered in Germany have led to significant cost reduction from some 100Euro/W for a complete installed PV system in the 1970s to about 1 Euro/W today. The progress in cost reduction can be displayed using the experience curve approach [10], see Figure 2.3 [11]. From this figure a so-called learning rate of $20 \%$ is derived; that is, with every doubling of capacity, price decreases by $20 \%$.

In many countries the amount of small $(1-10 \mathrm{~kW}$ size) residential systems is growing exponentially, as consumers are attracted by the low LCOE, which is lower than the retail electricity price, and this remains so for 25 years long; and the amount of PV will continue to grow. Very recently, the International Energy Agency (IEA) [12] forecasted that 50\% of the world's electricity supply would come from solar energy, of which PV will amount to one-third. This constitutes $4600 \mathrm{GW}$ to be installed in the coming 35 years. PV provides and will continue to provide renewable energy at a competitive price for consumers and utilities and at a market size of thousands of billion Euros; it evidently complies with the triple-P concept [13]: people, planet, and profit.

\subsubsection{PV Technology}

Solar PV systems are built up from PV modules and inverters that convert DC power to AC power, which can be fed into the electricity grid. PV modules of typically $1.6 \mathrm{~m}^{2}$ in size and with $250 \mathrm{~W}$ capacity consist of 60-72 PV series-connected silicon wafer-based 
cells of $15 \times 15 \mathrm{~cm}^{2}$ size and today form some $90 \%$ of the market [8]. The silicon wafers are sliced from large 6-inch highly purified silicon ingots. The manufacturing process involves an essential step in the creation of a so-called $\mathrm{p}-\mathrm{n}$ junction in the wafer. Further steps are needed for passivation and anti-reflection coatings, as well as for metal-based contacts. Other PV modules are based on thin films of cadmium telluride (CdTe), copperindium-selenide (CIS), and amorphous silicon (a-Si). These thin films have the advantage that they can be directly deposited on glass onto which a transparent conductive coating has been applied. This property makes them attractive for application as building integrated PV elements.

The PV capacity of systems and modules is always expressed in watt or rather watt-peak $\left(\mathrm{Wp}\right.$ ), as this is determined at standard test conditions involving $1000 \mathrm{~W} / \mathrm{m}^{2}$ solar intensity, equivalent to the light intensity of the sun at noon, which is denoted as 1-sun intensity. The efficiency of PV cells and panels depends somewhat on solar intensity, but PV power and solar intensity are closely linked. In terms of energy generation, the annual amount of solar irradiation is a key parameter. For example, a factor of about two exists between annual solar irradiation in the African Sahara and Northwest Europe; hence, the annual PV energy in the African Sahara is double the amount. Maps have been produced showing the potential of PV [14].

Technical developments in all material systems have led to impressive increases in conversion efficiency of up to $25 \%$ for the typical single $\mathrm{p}-\mathrm{n}$ junction solar cell [15]. Stacking two or more cells on top of each other improves the wavelength sensitivity such that conversion efficiencies of $44.4 \%$ have been reached [15]. Recently, rapid developments in the application of perovskites replacing organic dyes in dye-sensitized solar cells, have led to efficiencies approaching $20 \%$, while costs are believed to be much lower than silicon wafer-based solar cells [16].

PV system performance has also improved. A so-called performance ratio is defined, which is independent of irradiation and reflects various losses in the complete system, from module via inverter to grid connection. It compares actual performance (energy) with reference performance; the latter is determined at standard test conditions. Performance ratio is expressed in percent. In the early 1990s, performance ratio values of around $70 \%$ were common, while today, values of $85-90 \%$ are observed for well-performing systems [17]. These numbers can be used to estimate the annual energy yield by multiplying them with solar irradiance, where it should be noted that irradiance in the same plane of the PV modules, rather than horizontal irradiance, should be used.

\subsubsection{Environmental Issues}

Increased use of PV lowers GHG emissions in electricity generation considerably. Fossil fuel-based electricity generation typically emits some $400-1000 \mathrm{gCO}_{2}$-eq/kWh, depending on the type of fuel used and the power plant efficiency. In life-cycle assessment (LCA) studies on the GHG emissions of crystalline and thin film PV technologies, a range of 14-73 $\mathrm{gCO}_{2}$-eq/kWh was found, with thin-film PV being responsible for the lower values $[18,19]$. It should be noted that these emissions are predominantly indirect emission, caused by fossil-based electricity generation in the manufacturing process of PV cells [20]. Energy payback times of 1-2 years for various PV technologies have been determined, and prospective studies have indicated that these can be lowered to about 0.5 years $[21,22]$. 
If PV is to provide a major part of the world's energy demands, resource constraints may be prohibitive; in particular, material requirements for thin film PV (CdTe, CIS) allow for only $1-10 \%$ of the future demand [23]. It is also argued that amorphous silicon would be the PV technology providing the bulk of PW power. Requirements for metals such as copper and silver have been identified for PV in relation to other technologies [24]. In general, renewable technologies seem more metal-intensive than non-renewable technologies. For PV cells, silver used in electrical contacts is expected to be replaced by copper; however, copper usage is challenged by requirements for electricity networks [25].

\subsubsection{Outlook}

A recent IEA Technology roadmap [12] illustrates the importance of PV as one of the technologies supplying renewable electricity in 2050: the roadmap sates that the share of PV will be $16 \%$ in global electricity supply, at an installed capacity of $4600 \mathrm{GWp}$ in 2050 . It is also envisioned that the costs of PV will drop by $65 \%$ in 2050 compared to today's cost. PV will be applied in equal shares in the residential area as well as on a utility-scale.

Technological developments will be focused, as before, on increasing conversion efficiency as well as lowering cost. The IEA roadmap specifies several actions for solar cell and module development, such as reducing material consumption (to $3 \mathrm{~g} \mathrm{Si}$ per watt, and less silver), increase of module longevity, and development of PV for building and road integration. Actions are also defined for "system-friendly" deployment of PV to overcome the inherent variable characteristics of PV generation, such as PV forecast development, voltage and frequency regulation possibilities in PV inverters, management of load and flexibility, and development of storage capabilities.

\subsection{Wind Energy}

Wind energy has a long history. Old windmills were important producers of mechanical energy and in the seventeenth century, thousands of windmills were installed in North Western Europe enabling milling of grain and dry pumping of polders on a relatively large scale. After the industrial revolution, the steam engine (fired by coal) formed a cheaper, more powerful and more reliable "workhorse" as a result of which the windmills disappeared quickly from the landscape. The few remaining ones are nowadays mainly seen as industrial monuments (even though in the olden days they were considered to be severe visual pollution, similarly to the sometimes felt perception of modern wind turbines as described below).

The first oil crisis in 1973 together with the publication of "The Limits to Growth" by the Club of Rome [26] shocked the Western world, which suddenly realized its addiction to cheap and unlimited energy sources. This then made the time ripe to think on alternative energy sources, where wind energy was seen as one of the most promising ones. Thereto it was realized that wind energy is clean (the energy pay back time of a wind turbine is in the order of 3-6 months where the economical/technical life time of a wind turbine is 20 years), it is unlimited (the wind will always keep on blowing ...) and it adds to an energy independency from potential politically unstable countries. Since then, a rapid development took place where wind turbines (as they are called now) are used for the production of electrical energy opposite to the classical period where wind was used for the production of mechanical energy by wind mills (as the devices from those days are called). This has 


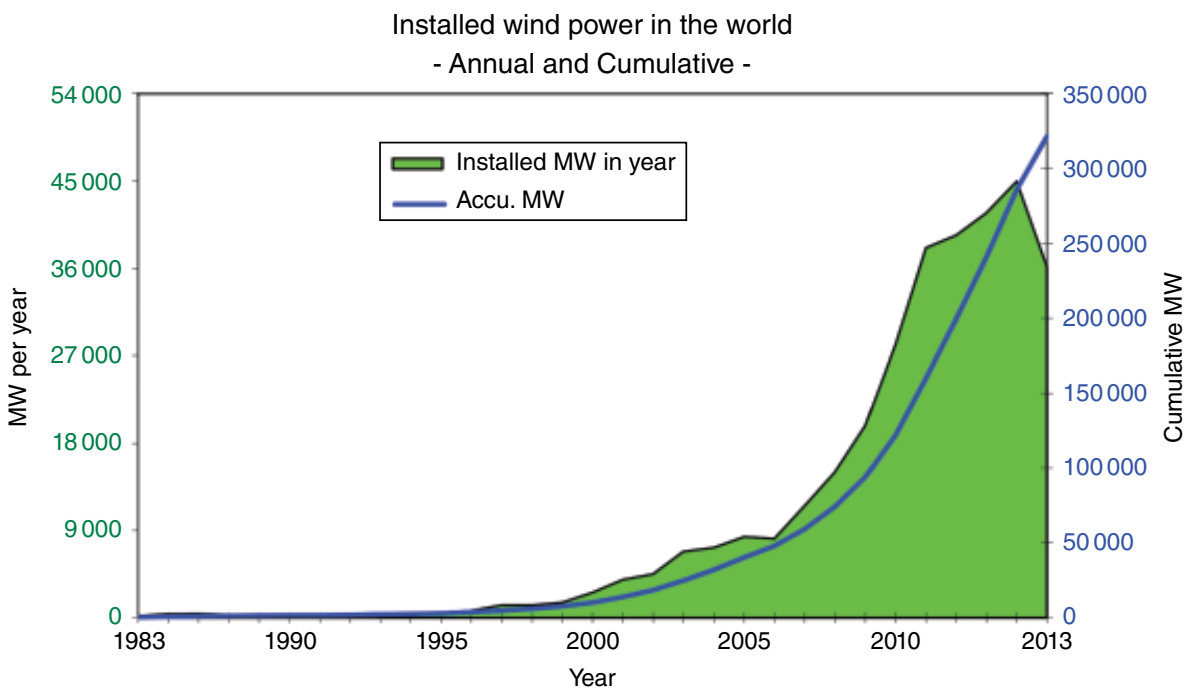

Figure 2.4 Installed wind power [27]. Source: Reproduced with permission from BTM consult [27]. (c) BTM consult.

culminated in the present situation where wind energy already contributes significantly to the secure electricity supply in various countries as will be described below.

The rapid development of wind energy since 1973 can be illustrated through several key performance indicators, for example, installed capacity, contribution to the overall energy demand, economic value, employment numbers, and state of the technology through the size of wind turbines etc.

Figure 2.4 shows the worldwide installed capacity in terms of annual and cumulative capacity for the period from 1983 until the end of 2013 [27] (note that these numbers are based on the summation of the nominal powers of all wind turbines. The "loss" in production due to the fact that a wind turbine does not continuously operate at nominal power is represented through a capacity factor. This capacity factor depends on the site and the turbine and generally varies between 28 and 40\%).

It can be seen that the worldwide installed capacity has grown to $320 \mathrm{GW}$. Figure 2.5 shows that since 2007 most of the installed capacity is found in Europe (120 GW at the end of 2013) but SE Asia (read China) has almost caught up with an installed capacity of $115 \mathrm{GW}$ [27].

The first wind turbines in the 1970s were often produced by idealistic entrepreneurs and they had diameters of a few meters and, consequently, very limited rated power of only a few kilowatt. Nowadays, the diameter of the largest commercial wind turbines is $126 \mathrm{~m}$ with a rated power of $7 \mathrm{MW}$ where prototypes exist with diameters larger than $150 \mathrm{~m}$, and turbines with diameters of more than $200 \mathrm{~m}$ and a rated power of $10 \mathrm{MW}$ are already designed [28].

Wind turbines are clustered together in so-called wind farms; for example, the large London Array farm with a rated power of over $600 \mathrm{MW}$. Wind turbine manufacturers have become large multinationals, for example, Vestas with approximately 16000 employees and Enercon with approximately 13000 employees. Also, large multidisciplinary multinationals like General Electric and Siemens have entered the wind energy scene and a large part of their turnover is now related to wind energy activities. 


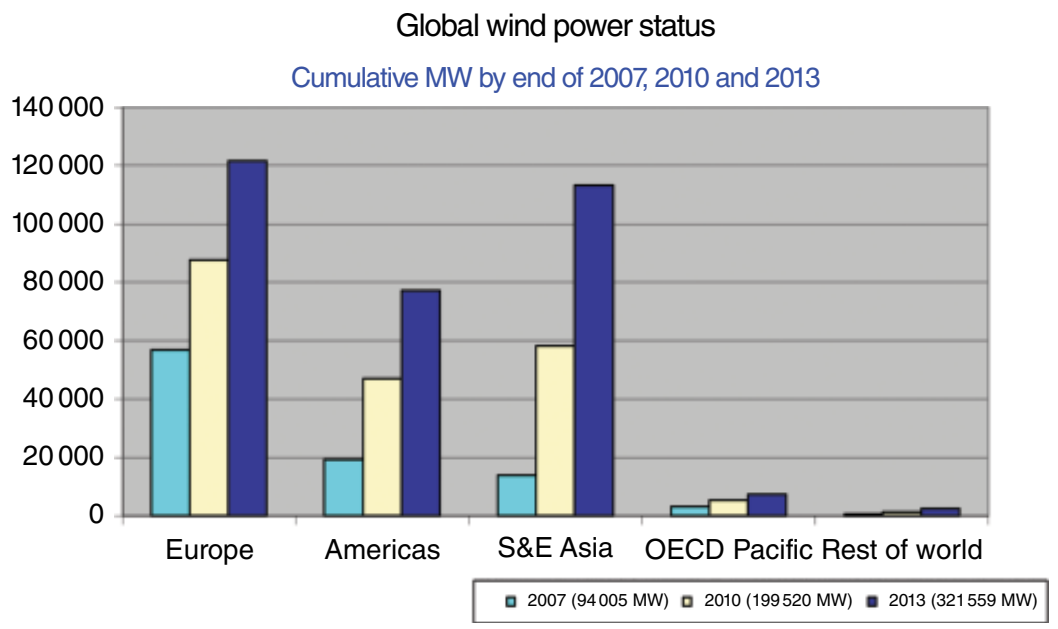

Figure 2.5 Installed wind power, distributed over the continents [27]. Source: Reproduced from BTM Consult [27], with permission from BTM consult.

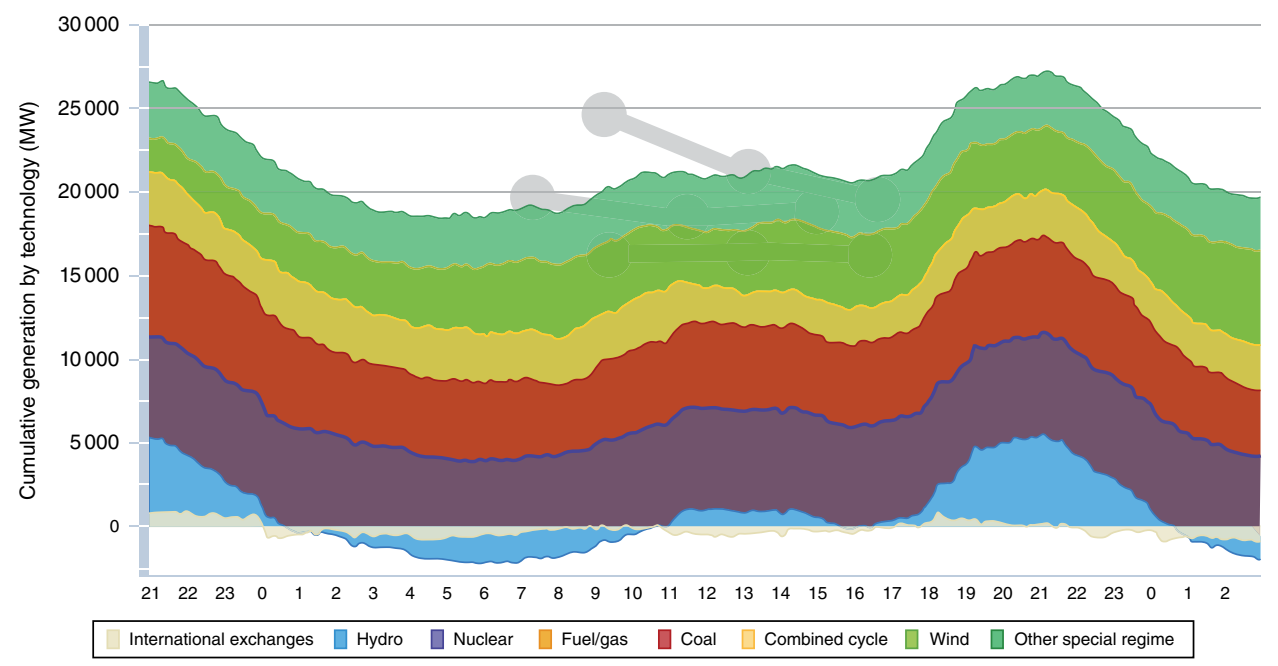

Figure 2.6 Contribution of energy sources on a representative day (November 3, 2014) in Spain. Source: Reproduced from https://demanda.ree.es/demandaGeneracionAreasEng.htm/ with permission from Red Eléctrica de España, www.ree.es.

According to [27] the economic value of wind energy in 2013 was in the order of 57 Billion Euro and at the end of 2013 wind energy contributed to $2.87 \%$ of the world's electricity production with much higher numbers in countries like Denmark (32.7\%) or Spain $(20.9 \%)$. This is illustrated in Figure 2.6, which shows the contribution to the energy demand in Spain on November 3, 2014 (a representative day) with wind Energy as the main contributor.

This growth went together with an impressive development of technology. Wind turbines are now the largest rotating machines on earth, which have severe challenges. One of the 
problems lies in the fact that wind turbines are the "world champion" fatigue machines (fatigue is a material problem starting with small cracks but eventually leading to failure). Other less visible technological challenges are due to the fact that wind turbines operate in a stochastic and very turbulent environment, which goes together with challenges on the field of grid integration and it leads to a very complicated aerodynamic behavior by which turbine design calculations require enormous computer resources [29]. Moreover, the giant wind turbines are placed more and more at offshore conditions, which makes them poorly accessible for maintenance personnel placing severe requirements on their reliability.

These technical challenges could only be overcome with high-level research. Already in the beginning of the 1980s several countries initiated national research programs on wind energy, the results of which soon found their way into technology improvements. Another example is the WTBE/ML project [30], one of the very first international cooperation projects in which wind turbine design codes were developed. These programs enabled an automated design approach in a systematic and scientific way leading to more reliable wind turbines.

\subsubsection{Social Acceptance and the Move Toward Offshore}

The rapid developments as described earlier went together with problems on the field of social acceptance. Although several investigations indicate a generally positive basic public perception on wind energy [31], massive deployment of wind energy suffers from the so-called not in my backyard (NIMBY) syndrome. Most complaints are related to noise hindrances and visual pollution. Several attempts have been undertaken to understand and improve social acceptance of wind energy, see for example, the recommended practices in Ref. [32]. A central theme in complaints is often found to be the little involvement of the local communities in the decision making process where potential benefits of wind energy for the local community are neither explained nor exploited. Moreover, social complaints can at least partly be mitigated with technological progress [33]. Here, examples are given of technological research that is devoted to the development of noise-reducing devices making wind turbines more silent as well as to bird collision detection systems, which proved that the impact of wind turbines on bird life is limited. Moreover, physical laws dictate that three-bladed turbines should rotate more slowly than two-bladed turbines (leading to less noise and less visual hindrance).

However, these insights have not taken away all public concerns, and the lack of social acceptance constituted the main drive to move toward offshore wind turbines; if placed far enough from the coasts, these are not visible and audible anymore. The first large-scale offshore wind farms entered the scene in the beginning of the millennium. At the end of 2013 [27] $6.8 \mathrm{GW}$ offshore wind power were installed, that is, $2.1 \%$ of the total installed wind power. Most of the offshore farms can be found in Europe (in particular, the UK). Although the contribution of off-shore wind energy is still limited, an enormous growth is expected: it is expected that in 2018 [27],there will be a fivefold growth of installed off-shore capacity to $32 \mathrm{GW}$.

\subsubsection{Costs/kWh}

One of the most important performance indicators is the costs/kWh. This parameter depends heavily on the wind climate and differs between on/offshore. It is estimated [34] that the costs of on-shore wind energy is between 7 Eurocents (near the coast) and 12.2 Eurocents (inland) per kilowatt hour. These numbers are more or less comparable to those 
Table 2.1 Scale factors for cost increase as function of water depth and distance to coasta.

\begin{tabular}{lllllllll}
\hline Depth $(\mathrm{m})$ & \multicolumn{7}{c}{ Distance to coast $(\mathrm{km})$} \\
\hline & $0-10$ & $10-20$ & $20-30$ & $30-40$ & $40-50$ & $50-100$ & $100-200$ & $>200$ \\
$10-20$ & 1 & 1.022 & 1.043 & 1.065 & 1.086 & 1.183 & 1.408 & 1.598 \\
$20-30$ & 1.067 & 1.090 & 1.113 & 1.136 & 1.159 & 1.262 & 1.501 & 1.705 \\
$30-40$ & 1.237 & 1.264 & 1.290 & 1.317 & 1.344 & 1.464 & 1.741 & 1.977 \\
$40-50$ & 1.396 & 1.427 & 1.457 & 1.487 & 1.517 & 1.653 & 1.966 & 2.232 \\
\hline
\end{tabular}

${ }^{a}$ Source: Data from European Environment Agency [36].

of [35], which shows that since the early 1980s significant cost reductions of more than a factor 3 have been achieved.

For offshore locations, very near the coast [34], it is estimated that the costs/kWh will be in the order of 13-15 Eurocents/kWh At these locations, wind farms are still visible from the coast, by which they do not take away all visual hindrance. Further from the coast the farms are not visible anymore but the cost increases due to higher costs of installation, foundation, grid connection, and operation and maintenance. This is illustrated in Table 2.1, which shows the cost increase as a function of the distance from the shore and water depth.

\subsubsection{Wind Energy in the Next Decade: Prognosis}

Figure 2.7 shows the expectation from [27] on the worldwide installed wind capacity. A steady growth is expected, that is, a doubling of capacity in 2018 to approximately $600 \mathrm{GW}$, which at that time will cover $7.3 \%$ of the worldwide electricity demand. In 2023, the installed capacity is expected to have grown to $900 \mathrm{GW}$.

Also, in the next decade, most of the installed capacity will be placed in Europe, the United States, and China where a proportional growth for the other continents is expected. An increasing part of this installed capacity will come from offshore wind energy in particular. This will be true in Europe where plans exist for very large wind farm clusters (e.g., the Doggersbank wind farm cluster of 7.2GW).

In order to reach the above mentioned numbers on installed capacity, social acceptance (and to a smaller extent the costs $/ \mathrm{kWh}$ ) are expected to be the main bottlenecks for onshore projects whereas for offshore projects the costs/kWh can be seen as the most important bottleneck.

Research efforts in several countries are currently intensified to overcome these bottlenecks. An overwhelming flood of ideas have been generated to reach cost reductions for offshore wind energy, for example, technological innovations on smart control systems and materials, optimization of operation and maintenance, logistics and grid integration, a more integrated system approach, more reliable design methods and so on. Also, mass production and cheaper financing means (due to lower anticipated risks) could reduce the overall costs/ $\mathrm{kWh}$ of offshore wind energy significantly.

\subsection{Geothermal Energy}

Geothermal energy technologies extract thermal energy from the earth. Geothermal energy can be used for generation of power or direct heat. Power generation is theoretically possible from reservoir temperatures of $100^{\circ} \mathrm{C}$ and higher, but commercial operations are 
Cumulative global wind power development

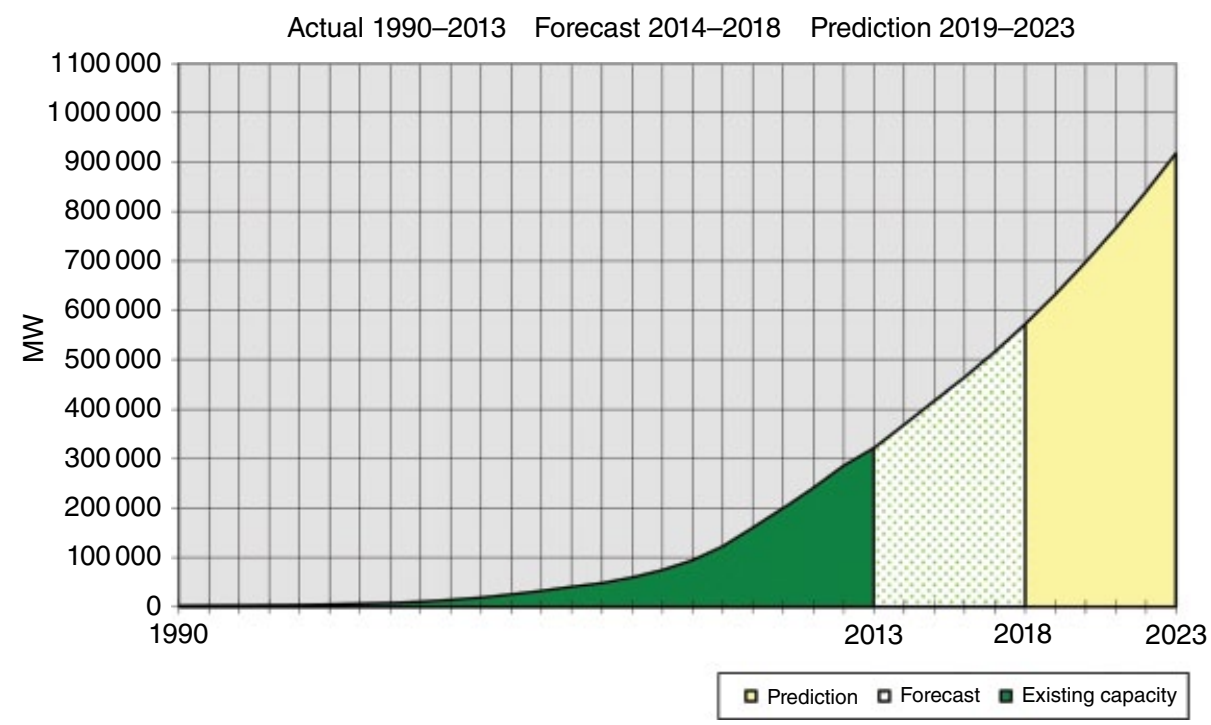

Figure 2.7 Expected global wind power development [27]. Source: Reproduced with permission from BTM consult.

generally marked by deploying hydrothermal reservoirs in excess of $200^{\circ} \mathrm{C}$. Direct use provides heating and cooling for various applications. Geothermal energy technologies also comprise (seasonal) storage of energy, which can be achieved in hydrothermal reservoirs/aquifers (ATES, aquifer thermal energy storage) or circulation of water through closed pipe loops buried in the ground (GSHP, ground source heat pump).

\subsubsection{Geothermal Development}

Hot springs have been used for bathing and heating purposes at least since Paleolithic times. An excellent overview of examples of geothermal energy harnessing heat from thermal springs before the twentieth century can be found in Ref. [37]. The oldest known spa is a stone pool on China's Mount Li built in the Qin dynasty in the third century BC. Romans deployed thermal spring waters at many places for public baths and underfloor heating. The world's oldest geothermal district heating system has been developed in Chaudes-Aigues, France, operating since the fourteenth century. The earliest industrial exploitation began in 1827 with the use of geyser steam to extract boric acid from volcanic mud in Larderello, Italy.

Geothermal power production was initiated by a commercial production plant of $250 \mathrm{~kW}$ geothermal power in Larderello in 1913 [38]. Larderello has been the only place with commercial power production until World War II. After World War II, geothermal power has gradually grown toward an installed capacity of $12.6 \mathrm{GW}$ globally in 2015 [39, 40] (Figure 2.8). The rapid growth in installed capacity in the 1980s as well as the rapid growth of produced electricity in the past two decades reflects the response to high prices of fossil fuel and incentives for renewable energy. During 2000-2015 the growth in installed capacity has been $60 \%$, whereas geothermal power produced has increased 


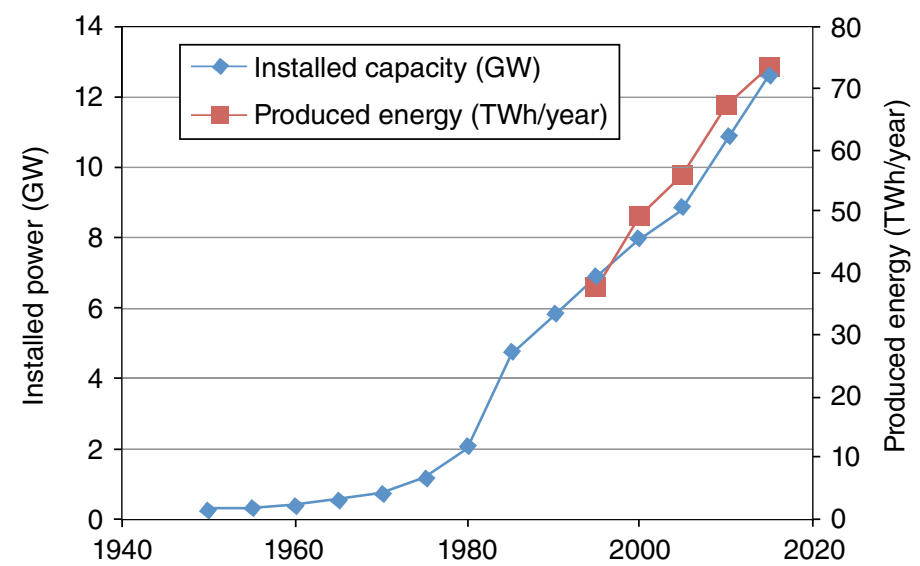

Figure 2.8 Installed capacity from 1950 up to 2015 (left, GW) and produced electricity (right, TWh/year) Source: Modified from Lund [38] and Bertani [39].

almost $50 \%$, marked by an increase in the reliability-capacity factor, being higher than $90 \%$ for most systems.

A significant potential for the growth of geothermal power production has been projected for 2050, including $100 \mathrm{GW}$ from conventional systems in magmatic areas and $100 \mathrm{GW}$ from EGS systems [41]. Growth of conventional systems is critically dependent on incentives for (foreign) investment in countries with significant magmatic potential and breakthrough in exploration technology for reducing pre-drill mining risk. In the 2000s there has been considerable optimism for the development of EGS [42]. However, there have been recently major concerns on induced seismicity related to reservoir stimulation causing projects to be suspended or halted [43].

A comprehensive study of the development of direct heat in the past decade has been performed by Refs. [44, 45]. They report the installed thermal power for direct utilization in 2015 to equal $70329 \mathrm{MW}_{\text {th }}$, growing at a compounded rate of over $10 \%$ over the past 10 years, with a current average capacity factor of $27 \%$. The thermal energy used is $587786 \mathrm{TJ} /$ year $(163287 \mathrm{GWh} /$ year), more than double the values of 2005 . The distribution of thermal energy used by each category is approximately $55.3 \%$ for ground-source heat pumps, $20.3 \%$ for bathing and swimming (including balneology), $15 \%$ for space heating, $4.5 \%$ for greenhouses and open ground heating, $2 \%$ for aquaculture pond and raceway heating, $1.8 \%$ for industrial process heating, $0.4 \%$ for agricultural drying, $0.5 \%$ for snow melting and cooling, and $0.2 \%$ for other uses. Energy savings amounted to 280 million barrels (42 million tonnes) of equivalent oil annually, preventing 133 million tonnes of $\mathrm{CO}_{2}$ being release to the atmosphere [45], which includes savings for geothermal heat pumps in the cooling mode (compared to using fuel oil to generate electricity).

\subsubsection{Geothermal Technology}

Geothermal energy technologies extract thermal energy from the earth, through producing hot fluids or vapor from production wells tapping into hydrothermal reservoirs. These reservoirs are marked by the presence of fluids (hence a reservoir can also be referred to as aquifer) and natural fluid flow paths allowing for subsurface draining of formation fluids into the 


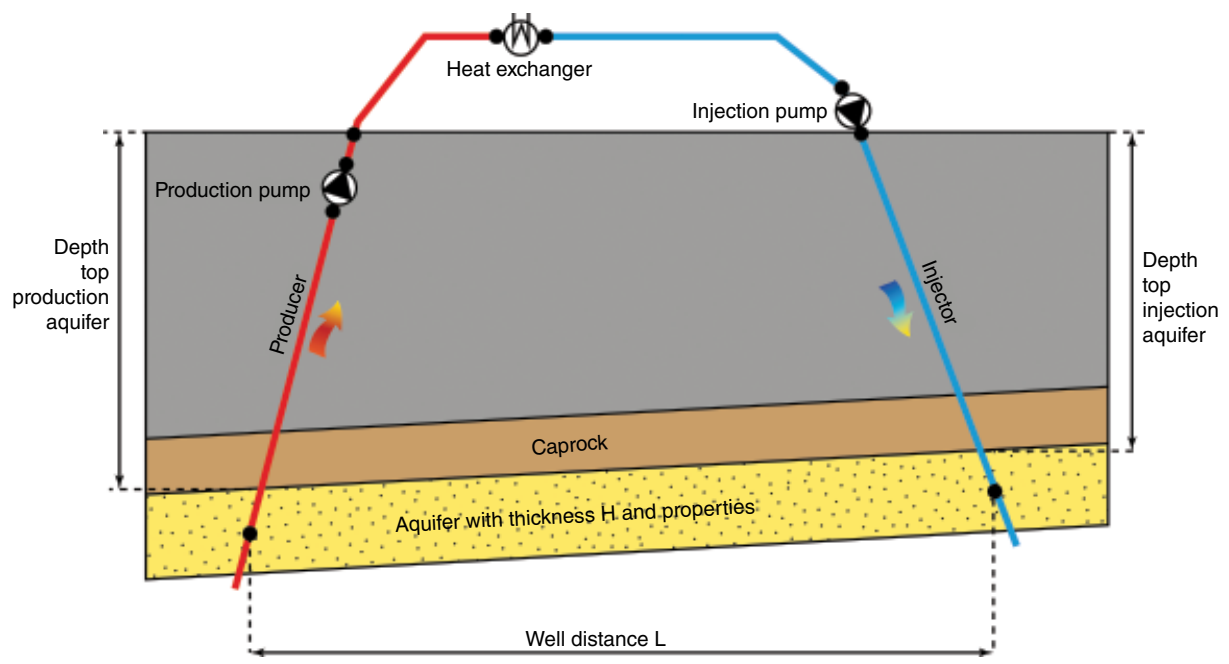

Figure 2.9 Geothermal doublet heat production system. Source: Modified after Di Pippo [46].

production well. For prevention of emission of formation fluids and gases in the environment, and pressure support in the reservoir, reinjection of produced and cooled formation fluids is often achieved by injection wells (Figure 2.9). These conventional production systems have been around for over 100 years, and are technologically mature for a large range of subsurface conditions. The natural fluid pathways are related to permeable pores in sedimentary or volcanic rocks or to permeable fractures. The abundance of reservoir rock types marked by permeable pores or fractures is limited, particularly with increasing depth and temperature. Enhanced geothermal systems (EGS) are marked by artificial or enhanced flow paths to allow for drainage. These systems hold a great promise for the future of geothermal energy, as these are not dependent on natural permeability and can theoretically be deployed anywhere [41, 42]. However, this technology is not mature, and is at a demonstration stage [47].

Geothermal power plants have a scalable capacity, starting from approximately $1 \mathrm{MW}$ up to $1000 \mathrm{MW}$ (e.g., $40 \mathrm{G5}$ ), feeding fluids (decompressed at the surface of so-called flash systems) and vapour from (multiple) wells into steam driven turbines. Conversion efficiency is strongly dependent on temperature ranging from 10 to $25 \%$ at 100 to $300^{\circ} \mathrm{C}$, respectively $[46,48]$. Geothermal power plants can extend the usable temperature range down to approximately $80^{\circ} \mathrm{C}$ by use of binary conversion systems, deploying a fluid with lower evaporation temperature than water.

Direct use provides heating and cooling for buildings including district heating, fish ponds, greenhouses, bathing, wells, and swimming pools, and water purification/desalination and industrial and process heat for agricultural products and mineral drying [44]. Furthermore, heat can also be used for chilling, by adsorption cooling. Direct heat can be produced in geothermal power plants, by deploying heat from wastewater. However, systems are often developed solely for direct heat production. Production temperatures can be enhanced by heat pumps, other sources of renewable heating, and combustion of fossil fuel. Thermal power is typically in $5-20 \mathrm{MW}_{\text {th }}$ for a single doublet ${ }^{1}$ system $[49,50]$.

\footnotetext{
${ }^{1}$ A doublet consists of one production well and one injection well.
} 
Geothermal energy extraction is considered sustainable, since geothermal energy production in all forecasted scenarios (e.g., [41]) is lower than the Earth's internal heat generation from radioactive decay estimated at ca 10TW [51]. Geothermal energy is available 24/7 and requires little surface space, thereby providing an attractive source of energy in densely populated areas.

Geothermal energy technologies comprise (seasonal) storage of energy, which can be achieved in hydrothermal reservoirs/aquifers (ATES) by circulation of water through closed pipe loops buried in the ground (GSHP). However, the nominal power of ATES and GSHP systems is in the range of kilowatt rather than megawatt.

In geothermal production systems and EGS, costs for drilling the wells to the reservoir represent the major investment for geothermal plants and increase exponentially with depth [42]. The produced temperature and achievable flow rates jointly determine the power of the geothermal system [52]. Temperatures vary strongly in the subsurface [40] (see Figure 2.10). In magmatic areas, the subsurface thermal gradient is high up to $200^{\circ} \mathrm{C} / \mathrm{km}$, allowing to reach favorable reservoir conditions at $1-3 \mathrm{~km}$ depth. LCOE is in the range of \$50-\$100/MW for geothermal electricity in these conditions [41].

Direct heat conventional systems (and EGS) can be developed in areas outside magmatic areas, marked by moderate to slightly elevated geothermal gradients of $20-50^{\circ} \mathrm{C} / \mathrm{km}$. LCOE is in the range of $\$ 50-\$ 100 / \mathrm{MW}_{\text {th }}$ for direct heat [40]. Economic performance critically depends on the capability to reach sufficiently high flow rates, which in turn is dependent on the occurrence of natural pores (and fractures). Pores are abundant in

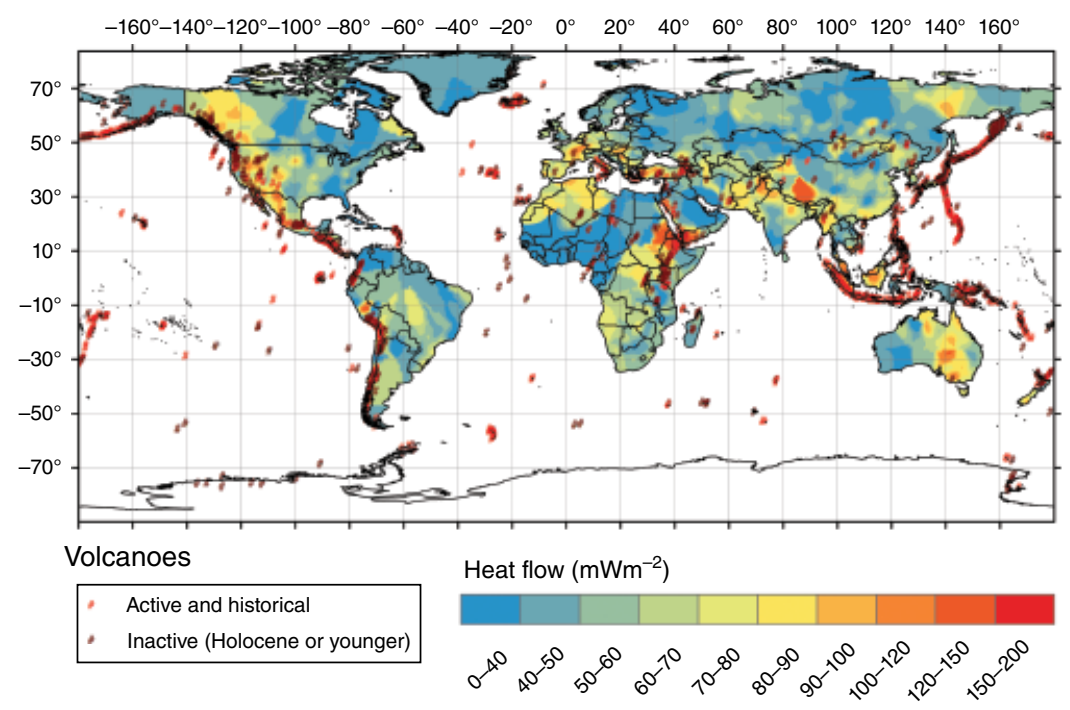

Figure 2.10 World heat flow map overlain by locations of (in) active volcanoes. Magmatic areas are well suitable for power production, whereas in other areas terrestrial heat flow is a good proxy for the thermal gradient indicative for favorable temperatures at moderate depth for direct heat production for heating and cooling and at deeper levels for electricity production (Source: www.thermogis.nl/worldaquifer). It is estimated that electricity generation and direct use of geothermal energy resources could reach more than 3 and 5\% respectively of the total world energy portfolio in 2050 [40, 52]. 
sedimentary rocks, which occur up to large depths in many regions in the world. Permeable fractures can also be found in basement rocks, underlying the sediments.

Geothermal energy storage (ATES and GSHP) is due to cost limitations for drilling depth limited to shallow depth levels (mostly $<1000 \mathrm{~m}$ ).

\subsubsection{Future Outlook}

There is significant potential for the future growth of geothermal power production projected for 2050 , including $100 \mathrm{GW}$ from conventional systems in magmatic areas and $100 \mathrm{GW}$ from EGS systems, that is, $3.5 \%$ of the projected final energy use [41, 44]. Growth of geothermal energy is critically dependent on incentives for (foreign) investment in countries with significant magmatic potential (e.g., Indonesia, marked by $27 \mathrm{GW}$ in over 200 identified prospects), and breakthrough exploration technology for reducing pre-drill mining risk.

State of the art in subsurface technologies have been largely developed originally in hydrocarbon exploration and production, and need to be adapted or developed from scratch to be cost-effective for EGS $[41,53,54]$. The outlook for future economic potential of EGS is bright [55], provided that drilling cost can be significantly reduced [42].

According to the IEA [41], Geothermal direct heat could contribute 5.8 EJ (1600TWh thermal energy) annually by 2050 , that is, $3.9 \%$ of the projected final energy for heat. For geothermal energy development, policy makers, local authorities and utilities need to be more aware of the full range of geothermal resources available and of their possible applications [41].

Finally, new technologies need to address public concerns regarding geo-hazards, through mitigation of unsolicited effects (e.g. induced seismicity, emission of fluids, and gases to the environment).

\subsection{Conclusion}

Supplying the energy needed in a sustainable manner in the future, say by 2050, requires a revolutionary approach in deploying a portfolio of renewable technologies. A combination of wind, PV, hydro, geothermal, and marine energy technologies can fully provide our energy needs, provided proper interconnections are present in combination with short- and long-term storage options. Many scenario's exist, which, based on assumptions provide various optimal mixes of technologies. One example is the set of scenarios that have been developed in the framework of the Global Energy Assessment [56]. Another is IEA's annually updated World Energy Outlook [57], which is updated using key world energy statistics [58].

This chapter has provided a brief overview of PV, wind, and geothermal energy developments in terms of capacity, performance and cost. Widespread deployment of these and other renewable technologies is foreseen as part of a portfolio of technologies that will provide the global energy demand in 2050 in a sustainable manner. Challenges per technology have been identified, but perhaps the main challenge is the integration of these techniques in the present or future electricity grid. This will require a revolutionary approach and will challenge business models of today's energy providers. 


\section{References}

1. REN21 (2014), Renewables 2014 Global Status Report, 2014, http://www.ren21.net/REN21Activities/ GlobalStatusReport.aspx (accessed November 14, 2014).

2. REN21 (2014), The First Decade: 2004-2014, 10 Years of Renewable Energy Progress, http://www. ren21.net/Portals/0/documents/activities/Topical\%20Reports/REN21_10yr.pdf (accessed November 14, 2014).

3. Musiol, F., Bickel, P., Nieder, T., Rüther, T. and Zimmer, U. (2013) Internet-Update ausgewählter Daten zur Broschüre Erneuerbare Energien in Zahlen, http://www.bv-agrar.de/sites/default/files/pdf/ info/statistik/bmu_eeg_update_dez2013.pdf (accessed November 14, 2014).

4. Friedlingstein, P., Andrew, R.M., Rogelj, J., Peters, G.P., Canadell, J.G., Knutti, R., Luderer, G., Raupach, M.R., Schaeffer, M., van Vuuren, D.P. and Le Quéré, C. (2014) Persistent growth of $\mathrm{CO}_{2}$ emissions and implications for reaching climate targets. Nature Geoscience, 7, 709-715.

5. Becquerel, E. (1839) Mémoire sur les effets électriques produits sous l'influence des rayons solaires. Comptes Rendus de L'Academie des Sciences, 9, 561-567.

6. Chapin, D.M., Fuller, C.S. and Pearson, G.L. (1954) A new silicon p-n junction photocell for converting solar radiation into electrical power. Journal of Applied Physics, 25, 676.

7. Prince, M.B. (1955) Silicon solar energy converters, Journal of Applied Physics, 26, 68-74.

8. Van Sark, W.G.J.H.M. (ed) (2012) Photovoltaic Solar Energy, Volume 1 in Comprehensive Renewable Energy (ed A. Sayigh), Elsevier, Kidlington, UK.

9. International Energy Agency, Photovoltaic Power Systems programme (2014) PVPS Report Snapshot of Global PV 1992-2013, Report IEA-PVPS T1-24:2014. International Energy Agency, Paris, France.

10. Junginger, M., van Sark, W. and Faaij, A. (eds) (2010) Technological Learning in the Energy Sector, Lessons for Policy, Industry and Science, Edward Elgar Publishing, Cheltenham, UK.

11. Chase, J. (2014) H1 2014 Levelised Cost of Electricity_PV, IEA Solar Electricity Roadmap Workshop, February 3-4, 2014, Paris, France, https://www.iea.org/media/workshops/2014/solarelectricity/ bnef2lcoeofpv.pdf (accessed December 2, 2014).

12. International Energy Agency (2014) Technology Roadmap Solar Photovoltaic Energy, 2014 edition. International Energy Agency, Paris, France, 60 pp.

13. Elkington, J. (1997) Cannibals with Forks: The Triple Bottom Line of 21 st Century Business, Capstone, Oxford, UK.

14. PVGIS, http://re.jrc.ec.europa.eu/pvgis/ (accessed December 1, 2014).

15. Green, M.A., Emery, K., Hishikawa, Y. Warta, W. and Dunlop, E.D. (2014) Solar cell efficiency tables (version 43), Progress in Photovoltaics: Research and Applications, 22, 1-9.

16. Grätzel, M. (2014) The light and shade of perovskite solar cells. Nature Materials, 13, 838-842.

17. Reich, N.H., Mueller, B., Armbruster, A., van Sark, W.G.J.H.M., Kiefer, K. and Reise Ch. (2012), Performance ratio revisited: Are PR $>90 \%$ realistic? Progress in Photovoltaics: Research and Applications, 20, 717-726.

18. Hsu, D.D., O’Donoughue, P., Fthenakis, V., Heath, G.A., Kim, H.C., Sawyer, P., Choi, J.-K. and Turney, D.E. (2012) Life cycle greenhouse gas emissions of crystalline silicon photovoltaic electricity generation. Journal of Industrial Ecology, 16, S122-S135.

19. Kim, H.C., Fthenakis, V., Choi, J.-K. and Turney, D.E. (2012) Life cycle greenhouse gas emissions of thin-film photo-voltaic electricity generation. Journal of Industrial Ecology, 16, S110-S121.

20. Reich, N.H., Alsema, E.A., van Sark, W.G.J.H.M., Turkenburg, W.C. and Sinke, W.C. (2011) Greenhouse gas emissions associated with photovoltaic electricity from crystalline silicon modules under various energy supply options. Progress in Photovoltaics: Research and Applications, 19, 603-613.

21. Mann, S.A., de Wild-Scholten, M.J., Fthenakis, V.M., van Sark, W.G.J.H.M. and Sinke, W.C. (2014) The energy payback time of advanced crystalline silicon PV modules in 2020: A prospective study. Progress in Photovoltaics: Research and Applications, 22 (2014) 1180-1194. 
22. Louwen, A., van Sark, W.G.J.H.M., Schropp, R.E.I., Turkenburg, W.C. and Faaij, A.P.C. (2015) Life cycle greenhouse gas emissions and energy payback time of current and prospective silicon heterojunction solar cell designs. Progress in Photovoltaics: Research and Applications. doi:10.1002/ pip. 2540

23. Kleijn, R. and van der Voet, E. (2010) Resource constraints in a hydrogen economy based on renewable energy sources: An exploration. Renewable and Sustainable Energy Reviews, 14, 2784-2795.

24. Kleijn, R., van der Voet, E., Kramer, G.J., van Oers, L. and van der Giesen, C. (2011) Metal requirements of low-carbon power generation. Energy, 36, 5640-5648.

25. Harmsen, J.H.M., Roes, A.L. and Patel, M.K. (2013) The impact of copper scarcity on the efficiency of 2050 global renewable energy scenarios. Energy, 50, 62-73.

26. Meadows, D.H., Meadows, D.L., Randers, J. and Behrens III, W.W. (1972) The Limits to Growth, Universe Books, New York.

27. BTM Consult (2014) World Market Update 2013 International Wind Energy Development Forecast 2014-2018, Navigant Consulting, Inc., Copenhagen, Denmark.

28. Schepers, J.G., Ceyhan, O., Savenije, F.J., Stettner, M., Kooijman, H.J., Chaviarapoulos, P., Sieros, G., Ferreira, C.S., Sørensen, N.N, Wächter, M., Stoevesandt, B., Lutz, T., Gonzalez, A., Barakos, G., Voutsinas, A., Croce, A. and Madsen, J. (2015) AVATAR: AdVanced Aerodynamic Tools for lArge Rotors. in Proceedings of 33rd ASME Wind Energy Symposium, January 5-9, 2015, Kissimmee, FL. American Society of Mechanical Engineers.

29. Schepers, J.G. (2012) Engineering models in wind energy aerodynamics—Development, implementation and analysis using dedicated aerodynamic measurements. PhD thesis, Delft University of Technology, Delft, the Netherlands.

30. Van Grol, H.J., Snel, H. and Schepers, J.G. (1991) Wind Turbine Benchmark Exercise on Mechanical Loads. A State of the Art Report. Volume 1, Part A \& B, Energy Research Center of the Netherlands, ECN, Petten, the Netherlands.

31. Eneco Energy Monitor, June 2013. Available at https://www.eneco.nl/over-ons/energiemonitor/ (accessed 9 July 2015).

32. IEA Wind (2013) Task 28, Expert group summary on recommended practices 14. Social acceptance of Wind Energy projects, IEA-wind. Available at https://www.ieawind.org/index_page_postings/RP/ RP\%2014\%20Social_Acceptance_FINAL.pdf

33. Schepers, J.G. (2013) Wind wins through education and research (In Dutch). Inaugural speech at University of Applied Sciences NHL, April 2013, Leeuwarden, the Netherlands.

34. Lensink, S. (ed), Conceptadvies SDE+2014, voor marktconsultatie (in Dutch), ECN-E-13-024. Energy Research Center of the Netherlands, Petten, the Netherlands.

35. Lantz, E., Wiser, R. and Hand, M. (2012) IEA Wind Task 26: The Past and Future Cost of Wind Energy, Work Package 2, NREL Report No. TP-6A20-53510. http://www.nrel.gov/docs/ fy12osti/53510.pdf (accessed March 25, 2015).

36. European Environment Agency (2009) Europe's onshore and offshore wind energy potential. Technical Report No 6/2009. EEA, Copenhagen, Denmark.

37. Cataldi, R., Hodgson, S.F. and Lund, J.W. (1999) Stories from a Heated Earth-Our Geothermal Heritage, Geothermal Resources Council, Davis, CA.

38. Lund, J.W. (2004) 100 Years of Geothermal Power Production GHC Bulletin, http://geoheat.oit.edu/ bulletin/bull25-3/art2.pdf (accessed March 25, 2015).

39. Bertani, R. (2012) Geothermal power generation in the world 2005-2010 update report. Geothermics, 41, 1-29.

40. Bertani R. (2015) Geothermal Power Generation in the World 2010-2014 Update Report. in Proceedings World Geothermal Congress, Melbourne, Australia, April 19-25, 2015. Available at https://pangea. stanford.edu/ERE/db/WGC/papers/WGC/2015/01001.pdf (accessed July 29, 2015).

41. IEA (2011) Technology Roadmap: Geothermal Heat and Power, OECD/IEA, Paris, France. 
42. Tester, J.W. (ed) (2006) The Future of Geothermal Energy-Impact of Enhanced Geothermal Systems (EGS) on the United States in the 21st Century-An Assessment by an MIT-led Interdisciplinary Panel, Massachusetts Institute of Technology, Cambridge, MA.

43. Majer, E., Nelson, J., Robertson-Tait, A., Savy, J. and Wong, I. (2012) Protocol for Addressing Induced Seismicity Associated with Enhanced Geothermal Systems. DOE/EE-0662. https://www1.eere. energy.gov/geothermal/pdfs/geothermal_seismicity_protocol_012012.pdf (accessed March 25, 2015).

44. Lund, J.W., Freeston, D.H. and Boyd, T.L. (2011) Direct utilization of geothermal energy 2010 worldwide review. Geothermics, 40, 159-180.

45. Lund, J.W. and Boyd, T.L. (2015). Direct Utilization of Geothermal Energy 2015 Worldwide Review. In Proceedings World Geothermal Congress, Melbourne, Australia, April 19-25, 2015. Available at https://pangea.stanford.edu/ERE/db/WGC/papers/WGC/2015/01000.pdf (accessed July 29, 2015).

46. Di Pippo, R. (2015). Geothermal power plants: Evolution and performance assessments. Geothermics, 53, 291-307.

47. Zimmermann, G., Moeck, I. and Blöcher, G. (2010) Cyclic waterfrac stimulation to develop an enhanced geothermal system (EGS): Conceptual design and experimental results. Geothermics, 39(1), 59-69.

48. Di Pippo, R. (2007) Ideal thermal efficiency for geothermal binary plants. Geothermics, 36 (3), 276-285.

49. Van Wees, J.-D., Kronimus, A., van Putten, M., Pluymaekers, M.P.D., Mijnlieff, H., van Hooff, P., Obdam, A. and Kramers, L. (2012) Geothermal aquifer performance assessment for direct heat production-Methodology and application to Rotliegend aquifers. Netherlands Journal of Geosciences, 91, 651-665.

50. Kramers, L., van Wees, J.-D., Pluymaekers, M.P.D., Kronimus, A. and Boxem, T. (2012) Direct heat resource assessment and subsurface information systems for geothermal aquifers; the Dutch perspective, Netherlands Journal of Geosciences, 91, 637-649.

51. IPCC (2011) Special Report on Renewable Energy Sources and Climate Change Mitigation. Chapter 4 geothermal energy. http://srren.ipcc-wg3.de/report/IPCC_SRREN_Ch04 (accessed March 25, 2015).

52. Cloetingh, S., van Wees, J.-D., Ziegler, P.A., Lenkey, L., Beekman, F., Tesauro, M., Förster, A., Norden, B., Kaban, M., Hardebol, N., Bonté, D., Genter, A., Guillou-Frottier, L., Ter Voorde, M., Sokoutis, D., Willingshofer, E., Cornu, T. and Worum, G. (2010) Lithosphere tectonics and thermomechanical properties: An integrated modelling approach for enhanced geothermal systems exploration in Europe. Earth-Science Reviews, 102 (3-4), 159-206.

53. Dumas, P., Van Wees, J.-D., Manzella, A., Nardini, I., Angelino, L., Latham, A. and Simeonova, D. (2014) Towards More Geothermal Electricity Generation in Europe GEO-ELEC Report, http://www. geoelec.eu/wp-content/uploads/2014/01/GEOELEC-report-web.pdf (accessed March 25, 2015).

54. Limberger, J., Calcagno, P., Manzella, A., Trumpy, E., Boxem, T., Pluymaekers, M. and van Wees, J.D. (2014). Assessing the prospective resource base for enhanced geothermal systems in Europe. Geothermal Energy Science, 2(1), 55-71.

55. Huenges, E. (ed) (2010) Geothermal Energy Systems-Exploration, Development, and Utilization, Wiley-VCH Verlag GmbH \& Co, Weinheim, Germany.

56. Nakicenovic, N. (ed) Global Energy Assessment, Toward a Sustainable Future, Cambridge University Press, Cambridge, UK.

57. International Energy Agency (2014), World Energy Outlook 2014. International Energy Agency, Paris, France.

58. International Energy Agency (2014), Key World Energy Statistics, 2014, International Energy Agency, Paris, France. 